\title{
Zagospodarowanie otoczenia szkół powszechnych w dwudziestoleciu międzywojennym na przykładzie Lubelszczyzny
}

\section{Elżbieta Przesmycka}

Politechnika Wroctawska .Wydziat Architektury

\section{Ewa Miłkowska}

\author{
Uniwersytet Przyrodniczo Humanistyczny w Siedlcach
}

Streszczenie: W okresie międzywojennym powstawało wiele założeń szkolnych. Większość z nich charakteryzowała dbałość o zagospodarowanie ich otoczenia. Autorki przedstawiają na kilku przykładach zasady zagospodarowania terenów przy szkołach na przykładzie realizacji na Lubelszczyżnie. Większość z projektowanych otoczeń szkół już nie istnieje, albo jest bardzo zmieniona, co często wpływa negatywnie na rodzimy krajobraz wielu miejsc w Polsce.

Słowa kluczowe: szkoły powszechne, otoczenie szkół, Lubelszczyzna

\section{Wstęp}

Po odzyskaniu niepodległości w 1918 roku na terenie Lubelszczyzny istniały bardzo trudne warunki na wielu polach życia gospodarczego, kulturalnego oraz naukowego. Wiele z tych sfer życia codziennego trzeba było zorganizować od początku. Szkolnictwo znajdowało się właśnie w takim stanie, iż władze zmuszone były do zorganizowania od nowa całej sieci szkół nie tylko powszechnych - dzisiejszych podstawowych ale także i na wyższych szczeblach.

Szkoły powszechne były w szczególnie trudnej sytuacji, gdyż przed w wybuchem I wojny światowej prawie wcale ich nie było na terenie Lubelszczyzny. Przyczyniła się do tego sytuacja wcześniejsza, zabory. Teren województwa znajdował się pod panowaniem rosyjskim, a tu nie rozwijano szkolnictwa. Co prawda istniały szkoły rosyjskie. Były jednak one nieliczne, o niezwykle dużych ilościowo klasach. Ludność polska z niechęcią patrzyła na nie, w obawie przed rusyfikacją młodzieży, ale nie tylko to było przyczyną rzadkiego uczęszczania do szkół dzieci polskich. W latach przedwojennych jak i po zakończeniu wojny na Lubelszczyźnie była wyjątkowo niska świadomość rodziców. Bali się oni posyłać dzieci do szkół oraz uważali to za zupełnie niepotrzebne.

Odzyskanie niepodległości, wprowadzenie polskich władz w miejsce dawnych rosyjskich, wprowadzenie języka ojczystego do urzędów w tym do placówek oświatowych ociepliło nieco stosunek społeczeństwa co do uczęszczania dzieci do szkół.

Władze widziały konieczność kształcenia młodego pokolenia oraz za wszelką cenę chciały ją umożliwić dzieciom niezależnie od tego skąd pochodziły (wieś, miasto) i niezależnie od tego jaki był status majątkowy ich rodziców. W 1919 roku, czyli już na początku II Rzeczypospolitej wprowadzono powszechnie obowiązujący dekret dotyczący obowiązku szkolnego. Dzieci od tego momentu musiały chodzić do szkoły, a władze miały to umożliwić i dopilnować.

O ile sytuacja lokalowa w innych zaborach nie była zła, na terenie Lubelszczyzny nie było ani szkół, ani nauczycieli. W pierwszych latach powojennych organizowano placówki szkolne w lokalach zastępczych tzn. 
w miastach były to wynajmowane pokoje w kamienicach czynszowych, na wsi natomiast izby szkolne aranżowano w chałupach mieszkańców. Nie były to miejsca dostosowane do nauki. Często ciasne pomieszczenia, niedostatecznie oświetlone, duszne i mało higieniczne.

W miarę upływu czasu sytuacja lokalowa szkół powszechnych poprawiała się. Uruchomiono programy budowy nowych szkół w Lublinie tzw. plan "mały" i "duży". Według planu "małego" w ciągu trzech lat miało powstać pięć gmachów szkolnych (na Wieniawie, przy ulicy Lipowej, Krochmalnej, na Bronowicach w miejscu starej rzeźni i na Kalinowszczyźnie). Plan "duży" miał być przeprowadzony w ciągu dziesięciu lat i miał doprowadzić do powstania dwudziestu trzech budynków nowych szkół?

Dodatkowo Ministerstwo Wyznań Religijnych i Oświecenia Publicznego wydało zeszyty poświęcone budownictwu placówek oświatowych. Zawierały one gotowe projekty budowlane wraz ze szczegółowo rozplanowanym terenem wokół szkół. Zabieg ten bardzo ułatwił procedurę powstawania nowych obiektów szkolnych, skrócił procedurę pozwoleń na budowę .

Budynki szkolne powstałe w dwudziestoleciu międzywojennym są niezwykle interesujące. Oprócz szczegółowo zaplanowanych pomieszczeń lekcyjnych uwzględniano mieszkania dla nauczycieli, bądź kierowników szkół, szatnie, pracownie tematyczne, a także pojawiają się sale gimnastyczne, choć nie są one zbyt częstym zjawiskiem.

Program funkcjonalny szkół uzależniany był od ilości dzieci mających uczęszczać do danej placówki. Małe obiekty przeznaczone dla jednej lub dwóch klas miały zazwyczaj jedną lub dwie sale lekcyjne, obszerny korytarz rekreacyjny i mieszkanie nauczycielskie. Większe szkoły miały dodatkowe pomieszczenia.

\section{Zagospodarowanie placów wokół szkół}

Tereny na których miały powstać szkoły powszechne były starannie wybierane. W miastach miano zadbać aby działka szkolna była usytuowana na uboczu, oddalona od domów mieszkalnych. Na budynki szkolne proponowano miejsca o ładnym i spokojnym otoczeniu. Najczęściej szkoły sytuowano nieco na uboczu miejscowości, na skrzyżowaniach głównych dróg. Każda nowo planowana szkoła powszechna była sytuowana na obszernej działce. Zawsze wydzielano boisko do gry w piłkę, plac gimnastyczny oraz ogród owocowo - warzywny przeznaczony do nauki ogrodnictwa dla dzieci. Osobno wydzielano ogród dla nauczyciela. Oprócz tego niemal każda szkoła miała wyznaczony plac apelowy przed szkołą oraz podwórze gospodarcze. Było ono niezbędne, gdyż trzeba było składować opał, dbać o otoczenie szkoły, a nauczyciel często trzymał także zwierzęta hodowlane. Większość szkół miała również wydzielone zaplecze sanitarne. Kanalizacja w tamtym okresie była luksusem i nawet szkoły usytuowane w mieście miały zewnętrzne sanitariaty, a wodę czerpano ze studni. Dodatkowo każda działka szkolna na obrzeżach była obsadzona wysokimi drzewami. Miały one tłumić ewentualny hałas oraz stwarzać cień w okresie większego nasilenia słonecznego.

\section{Wpływ wzorników na projekty zagospodarowania terenów przyszkolnych}

Tereny pod zabudowę szkolną były dokładnie zaplanowane. Międzywojenne wzorniki budynków szkół powszechnych, wydane przez Ministerstwo Wyznań Religijnych i Oświecenia Publicznego, podawały szczegółowe wytyczne, co do wymogów jakim powinny odpowiadać takie terenów. Zalecano, aby teren był położony w środku obwodu szkolnego. Dodatkowo należało zadbać, aby droga dzieci do szkoły była bezpieczna a także dostępna o każdej porze roku. Sam plac pod szkołę także miał być bezpieczny, cichy, położony z dala od ruchu ulicznego, trakcji kolejowych czy tramwajowych, oddalony od cmentarzy, głębokich jezior czy rzek oraz bagien. W miejscowościach, gdzie nie było wodociągów należało zadbać o studnię z wodą pitną.

Na gminach wiejskich ciążył obowiązek zapewnienia bądź wzniesienia domu dla nauczyciela. Dom dla nauczyciela mógł sąsiadować ze szkołą, ale powinien znajdować się na odrębnym placu.

Kształt i rozmiar działki powinien umożliwić umieszczenie budynku szkolnego, toalet, studni, budynków gospodarczych, a także mieszkań dla woźnego, nauczycieli, kierownika szkoły. Dodatkowo na działce powinny być przewidziane tereny pod boisko oraz ogród szkolny. Powierzchnia placu szkolnego była określona 
dla poszczególnych typów szkół i wynosić $5.500 \mathrm{~m}^{2}$ dla szkół niżej zorganizowanych (czyli jednoklasowych, dwuklasowych i trzyklasowych) oraz nie mniej niż $8.500 \mathrm{~m}^{2}$ dla pozostałych, w tym i bliźniaczych. W miastach uzyskanie tak dużego placu było często niemożliwe, więc ograniczano się tylko do wyznaczenia boiska sportowego, pomijając pozostałe elementy (nie było także potrzeby wznoszenia domu dla nauczyciela, ani organizacji ogrodu szkolnego) ${ }^{2}$.

Budynek szkoły wedle zaleceń ministerialnych miał być odpowiednio usytuowany względem stron świata, działek z nim sąsiadujących, dróg oraz ulic przylegających do placu szkolnego. Pomiędzy budynkiem szkolnym, a sąsiadującym z nim miała być zachowana odległość co najmniej 10 metrów (gdy był to budynek parterowy), i 20 metrów w przypadku budynku piętrowego. Na obszarach niezabudowanych należało zachować taką odległość, by powstające w przyszłości budynki na działkach sąsiednich nie zasłaniały światła słonecznego w salach lekcyjnych. Sam budynek szkolny zalecano projektować w głębi placu szkolnego, co najmniej 6 metrów od drogi. Miało to zapewnić bezpieczeństwo dzieci wybiegających ze szkoły.

Budynki gospodarcze oraz sanitariaty umieszczano w głębi działki, z dala od okien klas, tak aby uchronić dzieci przed drażniącymi zapachami. Studnia szkolna według zaleceń miała być oddalono o co najmniej 20 metrów od toalet i zabudowań gospodarczych.

Boisko szkolne oraz plac gimnastyczny zalecano oddalić od okien sal lekcyjnych, tak aby hałas towarzyszący zabawom dzieci nie dobiegał do pomieszczeń w których prowadzone były lekcje. Dodatkowo boisko jak i podwórze gospodarcze miały być widoczne zarówno z sal jak i z mieszkania nauczycielskiego ${ }^{3}$.

Przykłady modelowego rozplanowania terenu wokół szkół możemy zanalizować na podstawie projektów typowych zawartych we wzornikach szkół powszechnych wydanych w latach 1921-1926. Wzorniki te zostały przygotowane przez Ministerstwo Wyznań Religijnych i Oświecenia Publicznego, aby ułatwić pracę nad realizacją nowych placówek szkolnych. Zawierają one gotowe projekty szkół oraz szczegółowe wytyczne co do wznoszenia, oraz sytuowania nowych obiektów.

Modelowym przykładem może być projekt szkoły czteroklasowej nr 18 wykonany przez S. Filasiewicza (Ryc. 1).

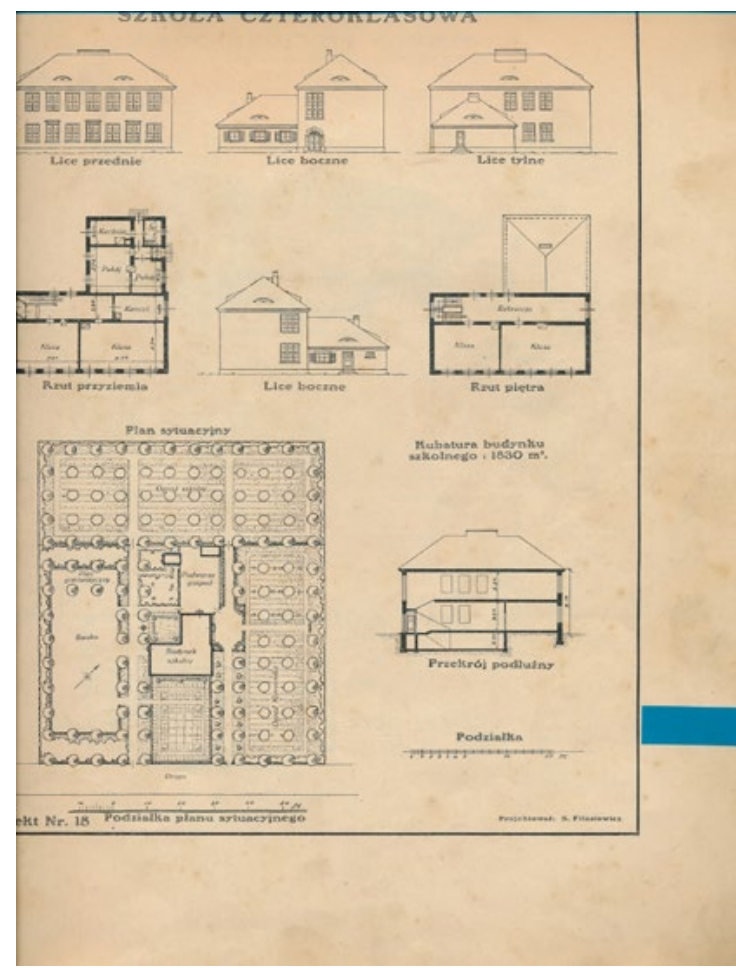

Ryc. 1. Modelowa szkoła czteroklasowa projekt $\mathrm{nr} 18$, (S. Filasiewicz), Projekty budynków szkót powszechnych, Warszawa 1925, zeszyt l, s. 55.

Ryc. 1. Model four-class school project no. 18, (S. Filasiewicz), Designs of common school buildings, Warsaw 1925, notebook I, p. 55 
Działka prostokątna o wymiarach $70 \times 100 \mathrm{~m}$ otoczona jest ze wszystkich stron wysokimi drzewami, $\mathrm{z}$ budynkiem szkolnym zaprojektowanym w głębi. Szkoła piętrowa o czterech klasach, z mieszkaniem dla nauczyciela. Na działce oprócz budynku szkoły zaplanowano podwórze gospodarcze przylegające do części budynku, w której ulokowano mieszkanie nauczycielskie. Podwórze wraz z budynkami gospodarczymi oraz toaletami osłonięto żywopłotem. Dodatkowo jest ono tak położone, aby nie było widoczne od strony drogi. Na działce szkolnej wydzielono również boisko z osobnym placem gimnastycznym oraz ogrody: szkolny i dla kierownika szkoły. Należy zauważyć, iż ponad 3/4 terenu wokół szkoły zajmowały ogrody z wieloma nasadzeniami drzew, w tym owocowych. Przed budynkiem szkoły została zachowana przepisowa odległość., a front szkoły podreślały ozdobne niskie nasadzenia.

Innym przykładem może być rozplanowanie działki pod szkołę dwuklasową ( model nr 6) zaprojektowane przez T. Majewskiego [Ryc. 2]. Jest to przykład działki niewielkiej, o wymiarach ok. 50x50 m, nieregularnej, zbliżonej do trapeza. W tym przypadku także zaplanowano budynek szkoły w głębi działki. Przewidziano również boisko, podwórze gospodarcze wraz z niezbędnymi budynkami, wydzielono miejsce na toalety oraz ogrody szkolne. Pomimo niewielkich rozmiarów działki znalazło się tu miejsce na dwa małe ogrody otoczone drzewami i żywopłotem.

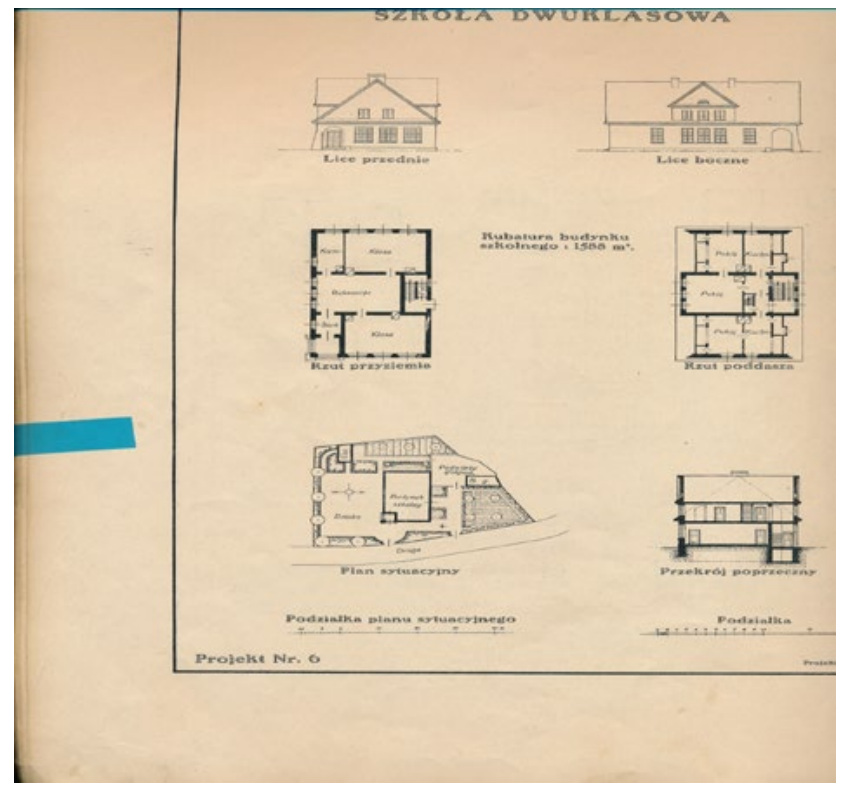

Ryc. 2. Ryc. 2. Modelowa szkoła projekt nr 6, (T.Majewski), Projekty budynków szkół powszechnych, Warszawa 1925, zeszyt I, s. 40.

Ryc. 2. Model school project No. 6, (T.Majewski), Designs of common school buildings, Warsaw 1925, notebook I, p. 40.

Szkoły wzorcowe były przewidziane dla wszystkich typów szkół od jednoklasowych po siedmioklasowe i bliźniacze - przeznaczone dla dwóch szkół w jednym budynku, najczęściej najwyżej zorganizowanych czyli siedmioklasowych. Projektanci przewidzieli, że nie wszystkie działki pod budynki szkolne będą modelowo prostokątne, więc w poszczególnych projektach znajdują się różne warianty rozplanowania terenów szkolnych. Jak pokazują przykłady szkół zrealizowanych w okresie dwudziestolecia międzywojennego, rzadko zdarzają się działki regularne. W przeważającym stopniu są one wielokątne, bardzo nieregularne.

Przykładem szkoły zrealizowanej w 1935 roku jest obiekt pięcioklasowy w Kijowcu w powiecie bialskim (Ryc. 3).

Szkoła została zrealizowana na działce wielokątnej. Od drogi głównej wiodącej przez wieś budynek został odgrodzony ogrodami szkolnymi, podzielonymi na regularne rabaty. W głębi działki zaplanowano boisko oraz podwórze gospodarcze wraz z odpowiednim zapleczem. 


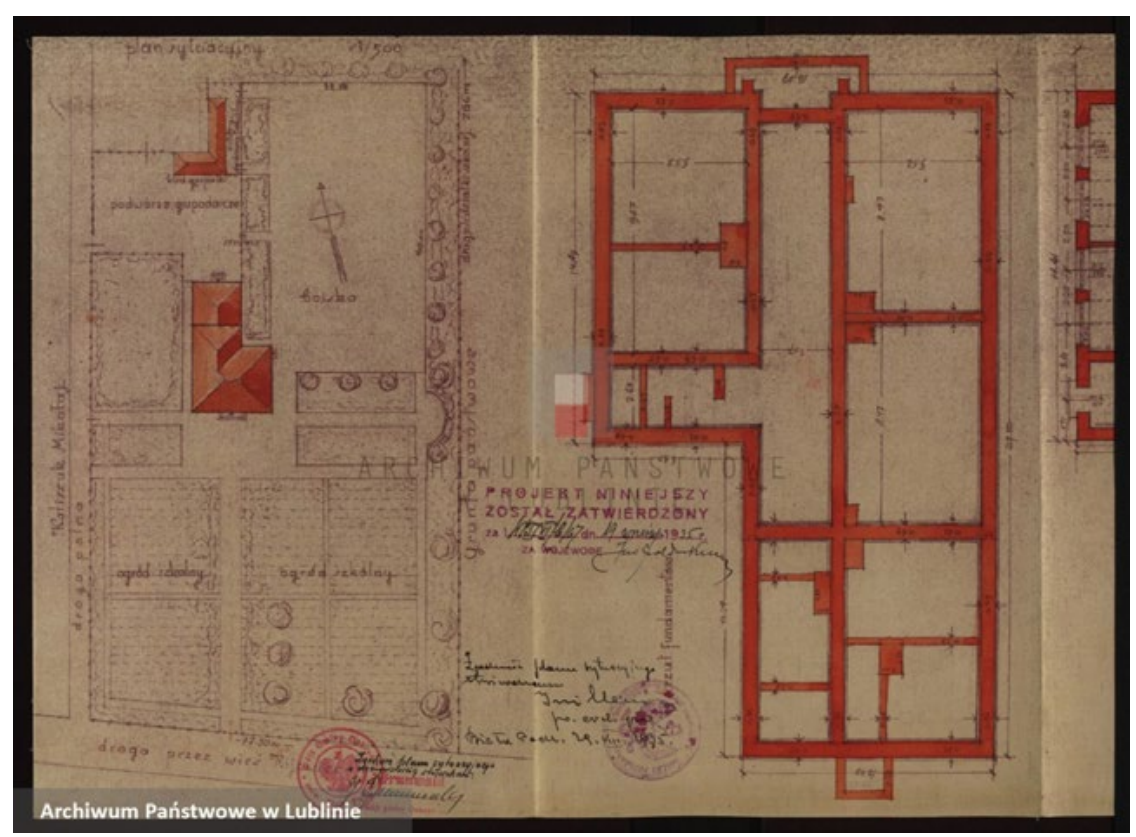

Ryc. 3. Kijowiec, szkoła pięcioklasowa, 1935, UWL $35 / 403 / 0 / 5.5 / 372$

Dig. 3. Kijowiec, five-grade school, 1935, UWL 35/403/0 / 5.5 / 372

Działkę nieregularną posiadała też szkoła w Krześlinie w powiecie siedleckim. Szkoła sześcioklasowa została wzniesiona w konstrukcji drewnianej na wydłużonej działce nieregularnej, położonej u zbiegu dwóch dróg: szosy do Siedlec oraz drogi wiodącej przez wieś (Ryc. 4). Działka została podzielona na dwie części. Na jednej wydzielono miejsce na boisko szkolne, rabaty kwiatowe, które zaplanowano w klinie przy drodze oraz w środkowej części wzniesiono budynek szkolny. Druga część była przeznaczona na umiejscowienie tu budynku mieszkalnego dla kierownika szkoły, który powiązano z podwórzem gospodarczym, toaletami oraz studnią przeznaczoną zarówno dla celów szkolnych jak i mieszkalnych nauczycieli.

Szkoła w Krześlinie była także budynkiem drewnianym. Takie rozwiązanie wzorniki międzywojenne rezerwowały dla obiektów szkół małych - do trzech klas. Jednak jak pokazuje praktyka tego okresu również szkoły duże nawet siedmioklasowe były wznoszone jako drewniane. W obiektach drewnianych mieszkania dla nauczycieli najczęściej były umieszczane w osobnych budynkach, tak jak to również rozwiązano w szkole w Krześlinie. Dodatkowo szkoły drewniane zalecano wznosić jako parterowe.

Przykładem ciekawego rozwiązania działki szkolnej jest otoczenie szkoły w Krasnymstawie (Ryc. 5). Szkołę tę zaplanowano już w 1930 roku, jednak plany zmodyfikowano w 1937. Była to szkoła bliźniacza, a dla takich obiektów trzeba było planować działki o większej powierzchni.

Szkoła w Krasnymstawie została zaprojektowana na nieregularnej działce położonej przy drogach głównych prowadzących do Lublina, Rejowca i Izbicy.

Działka szkolna wedle zaleceń dla obiektów szkół bliźniaczych była podzielona na dwie równe części. Na każdej z nich znajdowało się boisko, miejsce wydzielone na toalety szkolne oraz symetrycznie położone rabaty kwiatowe po obu stronach budynku szkolnego. Działka została przedzielona płotem, tak aby dzieci chodzące do różnych części szkoły nie mieszały się ze sobą na przerwach. Na środku placu szkolnego zaprojektowano studnię, wspólną dla obu szkół. 


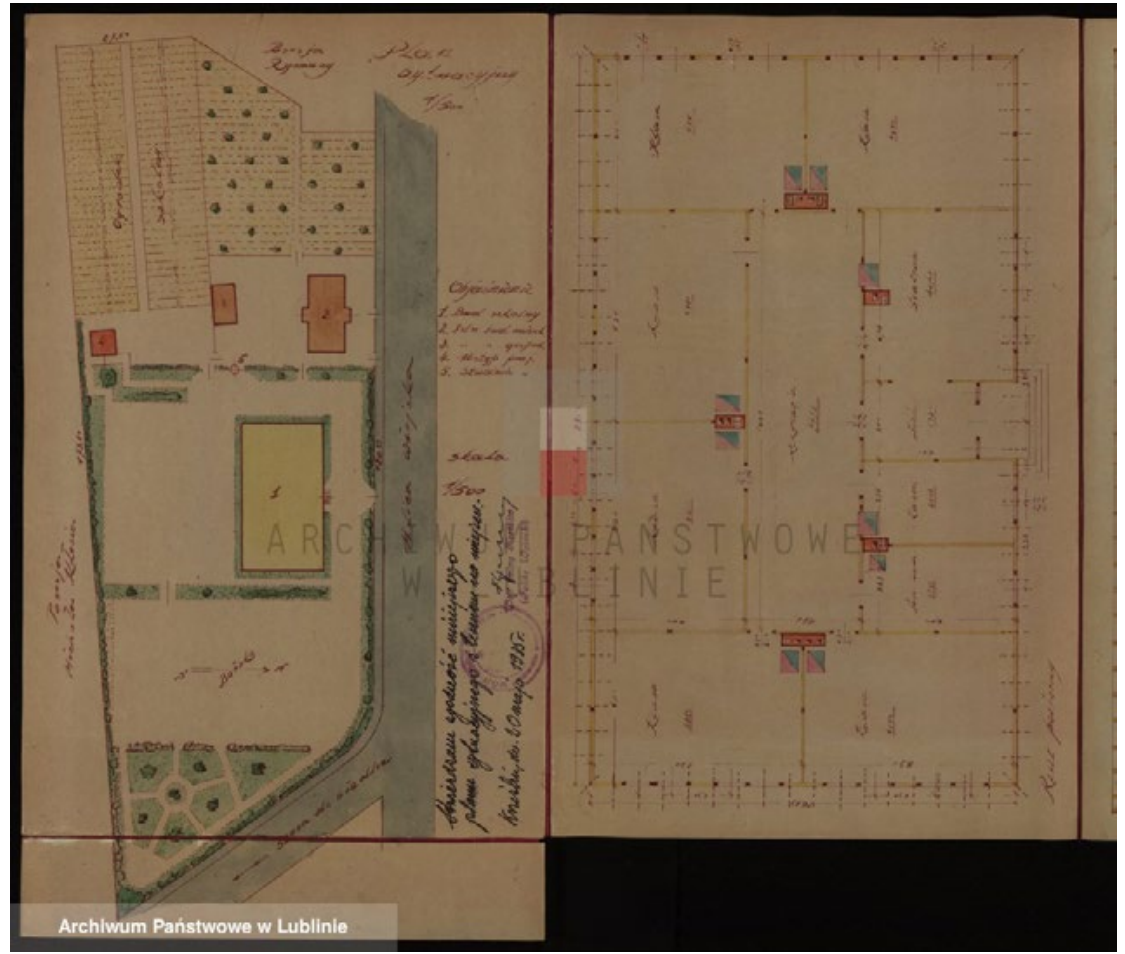

Ryc. 4. Krześlin, szkoła powszechna sześcioklasowa, powiat siedlecki, 1935, UWL 35/403/0/5.5/2220

Krześlin, six-grade general school, siedlecki powiat, 1935, UWL 35/403/0/5.5/2220

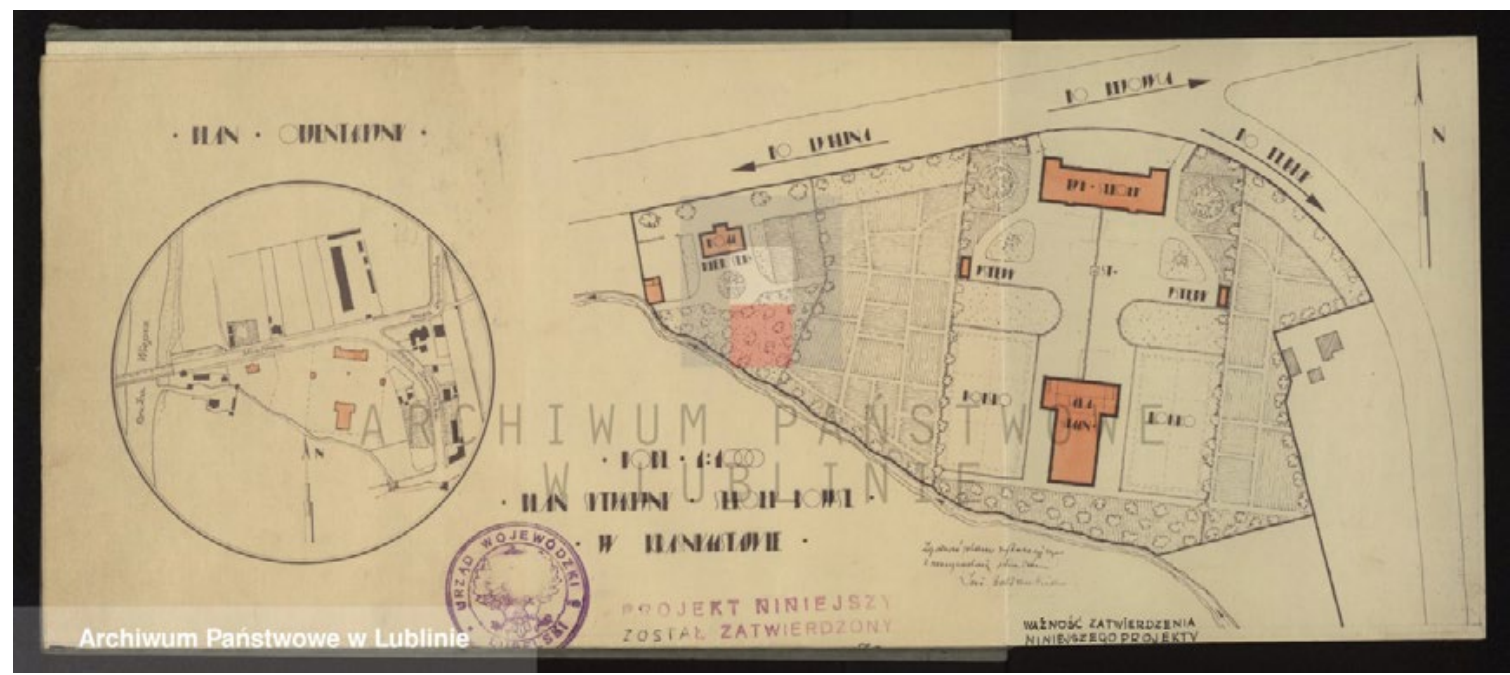

Ryc. 5. Szkoła bliźniacza w Krasnymstawie, plan zagospodarowania przestrzeni, UWL 35/403/0/5.5/1234 Twinning school in Krasnystaw, space development plan, UWL 35/403/0 / 5.5 / 1234

Szkoła w Krasnymstawie była obiektem zupełnie wyjątkowym (Ryc. 6). Jako jedna z nielicznych posiadała własną salę gimnastyczną. Sala była umieszczona w głębi działki szkolnej zlokalizowana w południowej części założenia , na osi widokowej z głównym budynkiem szkoły, tak aby uczniowie obu szkół mogli z niej korzystać. Dzieki takiemu rozplanowaniu budynków uzyskano wspólna przestrzeń rekreacyjna miedzy nimi. Ogrody dopełniały zewnętrzną część działki. Nie zapomniano o wprowadzeniu drzew jako osłonięcia całego terenu szkolnego po zewnętrznych jego granicach. Dodatkowo na działce zaprojektowano dom dla nauczycieli. Był on przepisowo oddzielony od zabudowań szkolnych. Umieszczony w ogrodzie, z osobnym podwórzem 
gospodarczym. Cześć ogrodową należącą do nauczycieli i kierownika oddzielno także wysokimi drzewami od strony przylegającej rzeki oraz sąsiednich parceli.

Jeszcze jednym przykładem zagospodarowania przestrzeni wokół szkół może być szkoła wzniesiona w Telczynie, w powiecie łukowskim. Projekt tej szkoły sporządzono w 1937 roku. Była to szkoła projektowana jako siedmioklasowa - czyli najwyżej zorganizowana. Szkoła w Telczynie została zaprojektowana przy drodze głównej wiodącej przez wieś. Działka szkolna była bardzo regularna, prostokątna. W głębi usytuowano murowany budynek szkoły, który z trzech stron otoczony był ogrodami szkolnymi. Za szkołą znajdowało się boisko, oraz podwórze gospodarcze wraz z zabudowaniami gospodarczymi. Na podwórzu zlokalizowano studnię z wodą pitną oraz toalety odgrodzone żywopłotem. Za boiskiem oraz podwórzem wydzielono część dla nauczyciela wraz z domem i osobnym ogrodem. Całość terenu szkolnego została obsadzona wysokimi drzewami - w tym wypadku lipami. Większość terenów przylegających do zabudowań szkolnych obsadzano lipami, co tyło związane zarówno z tradycją, jak tez dobrym wpływem tego gatunku drzew na klimat i jednocześnie na zdrowie dzieci.

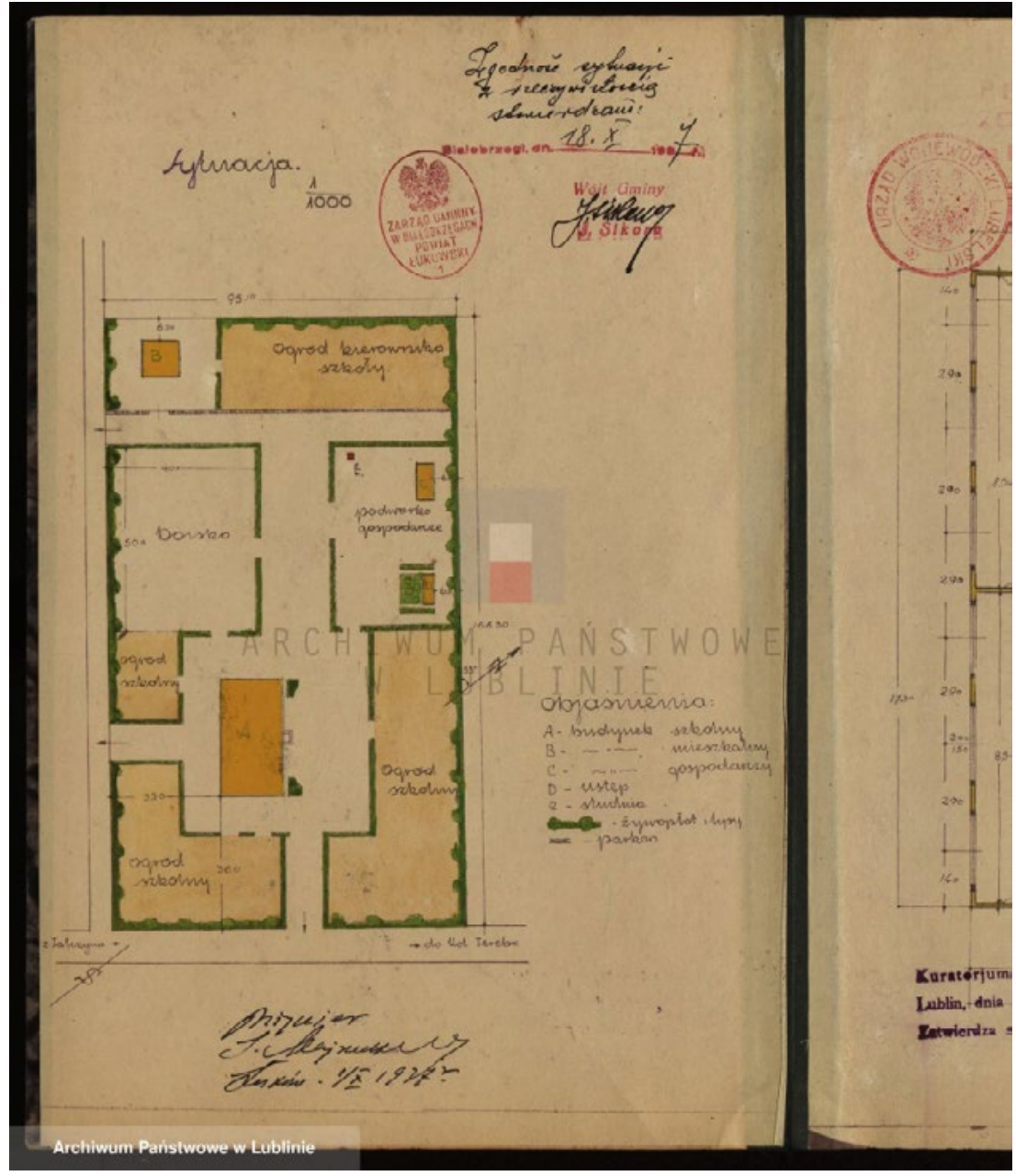

Ryc. 6. Telczyn, szkoła siedmioklasowa, UWL 35/403/0/5.5/1767

Telczyn, a seven-grade school, UWL 35/403/0 / 5.5 / 1767

\section{Podsumowanie}

Jak pokazuje praktyka, każda nowo wznoszona szkoła powszechna w okresie 1918-1939 miała szczegółowo rozplanowany teren wokół budynku. Projektanci tego okresu zwracali szczególną uwagę na bezpieczeństwo, oraz komfort dzieci uczęszczających do danej placówki. Widzieli konieczność prawidłowego projektowania 
boisk szkolnych oraz ogródków warzywno-owocowych, które w tamtym czasie spełniały doniosłą rolę dydaktyczną zwłaszcza na terenach wiejskich.

W okresie dwudziestolecia międzywojennego, w czasach niezwykle trudnych dla szkół, organizowano zaplecza szkolne zapewniając dzieciom i młodzieży dostęp do wody pitnej i toalet. Dbano również o dobro nauczycieli, którym zapewniano lokum w szkole lub w jej pobliżu. Zapewniano także minimalną intymność odgradzając część szkolną od części przeznaczanej dla nauczycieli i okolicznych terenów. Wyjątkową rolę pełniły drzewa takie jak lipy, jawory, akacje, sadzone tradycyjnie na terenach Polski. Wzbogacano tym również krajobraz miejscowości i miast. Niestety, wiele z tych założeń szkolnych dotrwała do czasów powojennych ulega dziś degradacji. Pierwszym powodem tego zjawiska jest częsta likwidacja małych szkół powszechnych położonych na wsi i w małych miastach. Drugą przyczyną zmian otoczenia szkół jest niekontrolowana działalność nauczycieli zmieniających charakter nasadzeń . z tradycyjnych, rodzimych gatunków znikają głównie drzewa liściaste, a zastępowane są najczęściej modnymi gatunkami żywotników, tui czy świerków srebrzystych . Wymianie, lub po prostu likwidacji ulega większość ogrodów, szczególnie warzywnych. Zastępowane są przeważnie miejscami zabrukowanymi stref przeznaczonych do parkowania. Charakterystyczne jeszcze niedawno w krajobrazie polskim grupy drzew otaczających szkoły z okresu międzywojennego stają się tylko wspomnieniem dawnej właściwej sztuki kształtowania otoczenia szkół, a co za tym idzie wdrażania tych idei młodemu pokoleniu uczniów.

\title{
Bibliografia
}

[1] Projekty Budynków Szkół Powszechnych, zeszyt I, Ministerstwo Wyznań Religijnych i Oświecenia Publicznego, Warszawa 1925

[2] Materiały Architektoniczne. Budowle użyteczności publicznej wsi i miasteczka, zeszyt I, szkoły powszechne, s. 9.

\section{Archiwum Państwowe w Lublinie}

[1] sygn. UWL 35/403/0/5.5/1767,

[2] sygn. UWL 35/403/0/5.5/1234,

[3] sygn. UWL 35/403/0/5.5/1234,

[4] sygn. UWL 35/403/0/5.5/2220,

[5] sygn. UWL 35/403/0/5.5/372

\section{Development of the surroundings of public schools in interwar period on the example of the Lublin region}

\begin{abstract}
Summary: In the interwar period, many school assumptions arose. Most of them were characterized by care for the development of their surroundings. The authors present, on a few examples, the rules for the development of lands near schools on the example of implementation in the Lubelszczyzna region. Most of the planned environments of schools no longer exist or are very changed, which often negatively affects the native landscape of many places in Poland.
\end{abstract}

Key words: general schools, school surroundings, Lublin region 